\title{
KELAYAKAN USAHA PERIKANAN BAGAN TANCAP DI PANGKALAN PENDARATAN IKAN (PPI) KABUPATEN BANGKA TENGAH
}

\section{LIFT NET BUSINESS FEASIBILITY IN FISH LANDING BASE (PPI) BANGKA TENGAH}

\author{
Elita Rotianti ${ }^{*}$, Kurniawan ${ }^{1}$, Teguh Ferdinand ${ }^{2}$ \\ ${ }^{1}$ Program Studi Manajemen Sumberdaya Perairan, Fakultas Pertanian Perikanan dan Biologi, \\ Universitas Bangka Belitung \\ Kampus Terpadu UBB, Gedung Teladan, Bangka, Kepulauan Bangka Belitung, 33172 Indonesia \\ ${ }^{2}$ Dinas Perikanan Kabupaten Bangka Tengah, Kepulauan Bangka Belitung \\ Komplek Perkantoran Pemerintah Kabupaten Bangka Tengah, Jalan titian puspa By Pass Koba, \\ Koba, Padang Mulia, Kabupaten Bangka Tengah, Kepulauan Bangka Belitung 33681 \\ Email: elitasena98@gmail.com
}

\begin{abstract}
ABSTRAK
Usaha bagan tancap dikategorikan alat tangkap ikan pelagis. Usaha penangkapan dengan alat tangkap Bagan Tancap merupakan usaha yang potensial dengan hasil tangkapan yang terus menerus serta memiliki harga jual yang tinggi. Tujuan penelitian ini adalah menganalisis kelayakan usaha dari penangkapan ikan dengan menggunakan alat tangkap bagan tancap di Pangkalan Pendaratan Ikan Desa Kurau Kabupaten Bangka Tengah. Penelitian ini dilaksanakan pada bulan November 2019, di (PPI) Kurau Kabupaten Bangka Tengah Provinsi Bangka Belitung. Penelitan menggunakan metode survei. Metode analisis kuantitatif yang digunakan yaitu dengan mengkaji aspek kelayakan usaha melalui pendekatan aspek finansial dengan menggunakan kriteria kelayakan investasi yang meliputi, Net Present Value (NPV), Net Benefit Cost Ratio (Net B/C), Internal Rate of Return (IRR), dan Payback Period (PP). NPV dari 11 nelayan semuanaya positif, B/C ratio > 1, PP (Payback Periode) semuanya dibawah 3 tahun, ROI 125,87 $\%$, dan nilai IRR rata-rata70 \% lebih besar dari nilai bunga, yang berarti semua kegiatan penangkapan usaha bagan tancap dapat dikatakan layak (feasible) dilanjutkan.
\end{abstract}

Kata kunci : PPI Kurau Bangka Tengah, Bagan Tancap, Kelayakan Usaha

\section{ABSTRACT}

The business of lift net is categorized as pelagic fish catcher. The attempted capture with lift net tool is a potential business with continuous catch and has a high selling price. The purpose of this study is to analyze the feasibility of fishing efforts by using a at Kurau Village Fish Landing Base in Bangka Tengah Regency. This research was conducted in November 2019, in PPI Kurau Central Bangka Regency Province of Bangka Belitung. This research uses survey methods. Quantitative analysis method used is to examine aspects of business feasibility through financial aspect approach using investment eligibility criteria including, Net Present Value (NPV), Net Benefit Cost Ratio (Net B/C), Internal Rate of Return (IRR), and Payback Period (PP). NPV of 11 fishermen is allnaya positive, B/C ratio > 1, PP (Payback Period) is all below 3 years, ROI 125,87 \%, and the average IRR value is $70 \%$ greater than the interest value, which means all business capture activities can be feasible continued.

Keywords : PPI Kurau Bangka Tengah, Bagan Tancap, Business Feasibility

\section{PENDAHULUAN}

Provinsi Kepulauan Bangka Belitung memiliki produksi perikanan tangkap sebesar $203.284,4$ ton dengan nilai penangkapan sebesar Rp 4.478.284.268.305. Salah satu potensi sumberdaya perikanan yang ada di Bangka Belitung ialah terdapat pada Wilayah Kabupaten Bangka Tengah dengan nilai tangkapan sebesar 25.068.94 (Dinas Perikanan Kabupaten Bangka Tengah, 2018). Potensi sumberdaya perikanan Kabupaten 
Bangka Tengah cukup besar sehingga dapat mendorong untuk meningkatkan perekonomian masyarakat. Salah satu daerah yang memiliki potensi sumberdaya perikanan tangkap terbesar yaitu di Desa Kurau.

Desa Kurau termasuk dalam wilayah Bangka Tengah, Kecamatan Koba, Kabupaten Bangka tengah yang terletak $\pm 29 \mathrm{~km}$ dari kota Koba dan $\pm 21 \mathrm{~km}$ dari kota Pangkalpinang. Kurau yang merupakan desa nelayan membuat sebagian masyarakat Desa ini berprofesi sebagai nelayan dan tempat tinggal mereka berada di pesisir pantai.Kegiatan Penangkapan ikan di desa Kurau ini memiliki basis penangkapan.Salah satu kegiatan perikanan tangkap di desa Kurau ini tedapat di pangkalan pendaratan ikan Kurau.

Pangkalan Pendaratan Ikan (PPI) Kurau terletak pada $106^{\circ} 14^{\prime} 02.585^{\prime \prime}$ BT dan $2^{\circ} 19^{\prime} 51.700^{\prime \prime}$ LS (Profil UPT PPI/TPI Kurau, 2018).Kegiatan penangkapan ikan di PPI Kurau masih tergolong sederhana dan tradisional. PPI kurau ini memiliki peranan penting dalam menunjang peningkatan produksi perikanan serta melayani terhadap seluruh kegiatan yang bergerak dalam bidang usaha perikanan, memperlancar arus lalu lintas kapal perikanan dan mendorong pertumbuhan ekonomi masyarakat perikanan, serta pada hakekatnya pelabuhan perikanan merupakan basis utama kegiatan industri perikanan tangkap yang harus dapat menjamin suksesnya aktivitas usaha perikanan tangkap di laut. Pelabuhan perikanan berperan sebagai terminal yang menghubungkan kegiatan usaha di laut dan di darat ke dalam suatu sistem usaha dan berdayaguna tinggi.Salah satu alat tangkap yang sering digunakan oleh nelayan di PPI Kurau ini ialah Bagan Tancap.

Perikanan bagan tancap yang merupakan alat tangkap tradisional, keberadaannya tetap dipertahankan oleh masyarakat nelayan yang hidup di sekitar pantai karena beberapa kelebihan yang di miliki salah satu alat tangkap ikan masyarakat bugis yang ada di Desa Kurau Barat.

Usaha penangkapan dengan alat tangkap bagan tancap merupakan usaha yang potensial dengan hasil tangkapan yang terus menerus serta memiliki harga jual yang tinggi. Berkaitan dengan hal tersebut, perlu diketahui sampai seberapa jauh kegiatan atau usaha perikanan tangkap bagan tancap masih dapat berjalan dan layak untuk diusahakan.

\section{METODE PENELITIAN}

Waktu pelaksanakan penelitian ini yaitu pada bulan November 2019, di Pangkalan Pendaratan Ikan (PPI) Kurau Kabupaten Bangka Tengah Provinsi Bangka Belitung. Pengambilan sampel dilakukan pada nelayan bagan tancap yang berada di Desa Kurau Kabupaten Bangka Tengah. Data primer selain melalui observasi langsung di lapangan juga melalui kuisioner dan wawancara dengan nelayan, untuk mengumpulkan datadata yang meliputi, modal yang diperlukan untuk investasi, biaya tetap (biaya perawatan dan biaya penyusutan unit penangkapan bagan tancap), biaya tidak tetap (biaya bahan bakar, pelumas, pembekalan makanan), dan Jumlah hasil penerimaan (produksi hasil tangkapan). Data sekunder yang diperoleh dari data Kantor Dinas Kelautan Perikanan Bangka Tengah meliputi data jumlah nelayan, data jumlah kapal, dan produksi hasil tangkapan bagan tancap.

Metode pengambilan sampel yang digunakan dalam penelitian ini adalah metode sensus. Sampling jenuh atau sensus menurut (Sugiyono, 2012) adalah teknik penentuan sampel bila semua anggota populasi digunakan sebagai sampel. Nelayan yang dijadikan sampel dalam penelitian ini adalah nelayan yang memiliki unit usaha penangkapan ikan dengan alat tangkap bagan tancap di Pangkalan Pendaratan Ikan (PPI) Kurau yang aktif beroperasi.Jumlah sampel pada penelitian ini sebanyak 11 sampel.

\section{Analisis Data}

Analisis yang digunakan dalam penelitian ini adalah analisis Deskriptif Kuantitatif. Menurut Sugiyono (2012) penelitian deskriprif kuntitatif yaitu, penelitian yang dilaukan untuk mengetahui nilai variabel mandiri, baik satu variabel atau lebih tanpa membuat perbandingan, atau menghubungkan dengan variabel lain. Metode analisis kuantitatif yang digunakan yaitu dengan mengkaji aspek kelayakan usaha melalui pendekatan aspek finansial dengan menggunakan kriteria kelayakan investasi yang meliputi, Net Present Value (NPV), Net Benefit Cost Ratio (Net B/C), Internal Rate of Return (IRR), dan Payback Period (PP), Data kuantitatif diolah menggunakan kalkulator dan komputer dengan Microsoft excel 2007. 


\section{Analisis keuntungan}

Analisis pendapatan usaha bertujuan untuk mengetahui besarnya keuntungan yang diperoleh dari suatu kegiatan usaha yang dilakukan (Djamin, 1984). Perhitungan pendapatan usaha dilakukan dengan menggunakan persamaan:

$$
\Pi=T R-(T C+\text { biaya implisit })
$$

Keterangan : $\Pi=$ Keuntungan; $T R=$ Total penerimaan; $\mathrm{TC}=$ Total biaya

Dengan kriteria : Jika TR > TC, kegiatan usaha mendapatkan keuntungan. Jika TR < TC, kegiatan usaha tidak mendapatkan keuntungan. Jika TR=TC, kegiatan usaha berada pada titik impas atau usaha tidak mendapatkan untung atau rugi.

\section{Analisis kelayakan usaha}

Return of Investment (ROI) merupakan parameter untuk mengetahui tingkat pengembalian investasi dari benefit (penerimaan) yang diterima pemilik. Kegiatan perikanan layak dikembangkan bila mempunyai nilai ROI > 1 (satu). Rumus yang digunakan adalah :

$$
\text { ROI }=\frac{\text { Keuntungan }}{\text { investasi }} \times 100 \%
$$

Analisis payback period merupakan analisis suatu periode yang diperlukan untuk menutup kembali pengeluaran investasi dengan menggunakan aliran kas (Pratama et al., 2012). analisis Payback Period dapat diketahui dengan rumus berikut:

$$
\mathrm{PP}=\frac{I}{\pi} \times 1 \text { tahun }
$$

Keterangan : PP = Payback Period; $I=$ Investasi; $\pi=$ Keuntungan

Kriteria : Nilai Payback Period kurang dari 3 tahun pengembalian modal usaha dikategorikan cepat. Nilai Payback Period 3-5 tahun kategori pengembaluian sedang. Nilai Payback Period lebih dari 5 tahun dikategorikan pengembalian lambat

Net Present Value (NPV) yaitu selisih antara present value dari investasi dan nilai sekarang dari penerimaan-penerimaan kas bersih (arus kas operasional maupun arus kas terminal) di masa yang akan datang.Analisa NPV dapat diketahui dengan rumus :

$$
N P V=\sum_{\mathrm{t}=1}^{n} \frac{\mathrm{Bt}-\mathrm{Ct}}{(1+t)}
$$

Keterangan : $\mathrm{Bt}=$ Keuntungan dari suatu usaha pada tahun ke- $t$; $\mathrm{Ct}=$ Biaya dari usaha pada tahun ke- $t$; I = tingkat suku bunga yang berlaku; $\mathrm{t}=$ tahun ke-; $\mathrm{n}=$ jumlah tahun.

Pengambilan keputusan dengan Kriteria : NPV $>1$; maka usaha tersebut layak; NPV = 0 ;maka usaha tersebut dapat layak; NPV $<1$ ; maka usaha tersebut tidak layak (Umar, 2003).

B/C Ratio (Benefit Cost Ratio) adalah ukuran perbandingan pendapatan (Benefit= B) dengan total biaya produksi (Cost $=\mathrm{C}$ ). Dalam batasan besaran nilai B/C dapat diketahui apakah suatu usaha menguntungkan atau tidak menguntungkan.

$$
\mathrm{B} / \mathrm{C} \text { ratio }=\text { Benefit } / \mathrm{TC}
$$

Keterangan: Benefit $=$ Pendapatan; $T C=$ Total Cost ( Biaya Total);

Dengan kriteria: $\mathrm{B} / \mathrm{C}>1=$ Usaha layak dilaksanakan; $\mathrm{B} / \mathrm{C}<1$ : Usaha tidak layak atau merugi;

Internal Rate of Return (IRR) menurut Dahlan (2011) adalah merupakan tingkat bunga yang akan menjadikan jumlah nilai sekarang dari produk sama dengan jumlah nilai sekarang dari pengeluaran modal. Nilai IRR dapat dihitung dengan menggunakan rumus:

$$
\mathrm{IRR}=\mathrm{It}+\frac{\mathrm{NPV} 1}{\mathrm{NPV} 1-\mathrm{NPV} 2}(\mathrm{i} 1-\mathrm{i} 2)
$$

Keterangan: $\mathrm{i}_{\mathrm{t}}=$ tahun $\mathrm{ke}-; \mathrm{i} 1=$ tingkat bunga ke- $1 ;$ i 2 = tingkat bunga ke-2; NPV1 = NPV pada tingkat bunga i1; NPV2 = NPV pada tingkat bunga i 2 .

Usaha dikatakan layak jika, IRR > discount rate, sedangkan usaha dikatakan tidak layak jika IRR < discount rate.NPV <1; maka usaha tersebut tidak layak (Umar, 2003).

\section{HASIL DAN PEMBAHASAN}

Hasil kuisioner dapat diketahui identitas responden diantaranya umur, dan lama usaha yang telah dilakukan oleh nelayan bagan tancap di PPI Kurau Kabupaten Bangka Tengah dapat dilihat pada Tabel 1. 
Adapun rata-rata umur nelayan bagan tancap di PPI Kurau Bangka Tengah ini berkisar antara 32-86 tahun serta lama usaha yang sudah dijalankan rata-rata 15 tahun. Dari hasil penelitian dengan nelayan pemilik bagaan tancap di PPI Kurau, hanya memiliki 1 anak buah kapal (ABK). Hal ini juga di kemukakan oleh Takril (2005) bahwasannya nelayan yang dibutuhkan dalam pengoperasian bagan tancap tidak terlalu banyak, cukup satu atau dua orang saja karena tugasnya hanya untuk menurunkan dan menaikkan jaring bagan pada saat pengoperasian alat tangkap tersebut.

Tabel 1. Identitas Responden

\begin{tabular}{lccc}
\hline No & Nama & $\begin{array}{c}\text { Umur } \\
\text { (Tahun) }\end{array}$ & $\begin{array}{c}\text { Lama Usaha } \\
\text { (Tahun) }\end{array}$ \\
\hline 1 & Samsudin & 55 & 8 \\
2 & Lematiro & 82 & 25 \\
3 & HJ. Akbar & 74 & 30 \\
4 & Arsad A.S & 56 & 20 \\
5 & Riski & 30 & 10 \\
6 & Mustring & 50 & 10 \\
7 & Alias & 30 & 10 \\
8 & Tulla & 72 & 15 \\
9 & Misran & 38 & 13 \\
10 & Udro & 43 & 10 \\
11 & Alimudin & 49 & 15 \\
& Rata-Rata & & 15 \\
\hline
\end{tabular}

Sumber: Data Olahan Penelitian, 2020

\section{Kontruksi Bagan Tancap}

Bagan tancap merupakan alat tangkap yang umumnya digunakan oleh nelayan suku bugis di PPI Kurau Bangka Tengah untuk menangkap ikan-ikan pelagis. Kontruksi alat tangkap bagan tancap Kurau Kabupaten Bangka Tengah sebagaimana tersaji pada Tabel 2.

Alat tangkap bagan tancap di perairan Kurau terdiri dari rangkaian atau susunan bambu berbentuk persegi empat yang ditancapkan di perairan, dipasang atau diset menetap di daerah penangkapan dan pada bagian tengah dari bangunan tersebut dipasang jaring. Jumlah bambu yang digunakan bervariasi antara 135-200 batang untuk menopang berdirinya alat tangkap bagan tancap di perairan. Jaring yang ukuran meshsize 0,5 cm. Mempunyai ukuran $6 \times 6 \mathrm{~m}$ dan dihubungkan dengan tali pada keempat sisinya yang berfungsi untuk menarik jaring dan diberi pemberat untuk menenggelamkan jaring dan memberikan posisi jaring yang baik selama berada dalam air dan berfungsi untuk memudahkan pengoperasian alat tangkap. Kayu yang sering digunakan oleh kebanyakan nelayan di PPI Kurau yaitu kayu Gelam.

Tabel 2. Kontruksi Bagan Tancap

\begin{tabular}{lll}
\hline Komponen & Bahan & Jumlah \\
\hline Rumah Bagan & Atap & \pm 100 buah \\
& Lantai & \pm 20 buah \\
& Dinding & \\
Jaring bagan & wareng & 1 \\
Lampu bagan & & \pm 15 \\
Peralatan bagan & Kayu & 32 buah \\
& Bambu & 65 buah \\
& Sangker & 20 buah \\
Kayu & & \\
$\begin{array}{l}\text { Penyanggang } \\
\text { Bagan tancap }\end{array}$ & Kayu gelam & \\
\hline
\end{tabular}

Daerah Pengoperasian dan pengangkatan jaringJarak yang ditempuh oleh nelayan bagan tancap di Kurau ke lokasi daerah pengoperasian bagan tancap rata-rata 50-60 menit. Pengoperasian bagan tancap oleh nelayan Kurau di mulai pada waktu pengoperasiannya dari pukul 19.30-04.30 dengan waktu hauling setiap 2-3 jam sekali dimana dalam satu malam terdapat 6 kali hauling. Pengangkatan jaring dilakukan setelah kawanan ikan terlihat berkumpul dilokasi penangkapan. Kegiatan ini diawali dengan pemadaman lampu secara bertahap, hal ini dimaksudkan agar ikan tersebut tidak terkejut dan tetap terkonsentrasi pada bagian bagan di sekitar lampu yang masih menyala.Ketika ikan sudah terkumpul di tengah-tengah jaring, jaring tersebut mulai ditarik ke permukaan.

\section{Biaya}

Biaya merupakan komponen pengeluaran yang harus dikeluarkan. Biaya pada usaha perikanan tangkap dibedakan menjadi dua yaitu biaya tetap (fixed cost) dan biaya tidak tetap (variable cost) dapat dilihat pada Tabel 4 dan Tabel 5.

Biaya merupakan komponen pengeluaran yang harus dikeluarkan. Biaya pada usaha perikanan tangkap dibedakan menjadi dua yaitu biaya tetap (fixed cost) dan biaya tidak tetap (variable cost). Biaya awal untuk kegiatan usaha perikanan bagan tancap dari 11 responden rata-rata sebesarRp. 52.335.364/tahun, untuk biaya tidak tetap (variable cost) sebesar Rp. 
$35.11 .636 /$ tahun, besarnya biaya tidak tetap ini rata-rata yang dikeluarkan untuk BBM dan biaya pembekalan dimana biaya ini dikeluarkan pada saat usaha sedang beroperasi.

Biaya tetap dari 11 responden rata-rata sebesar Rp.18.847.289/tahun, biaya tetap dikeluarkan pada usaha bagan tancap ini karena berisi komponen penyusutan dan perawatan-perawatan yang dilakukan setiap bulan walaupun usaha sedang tidak beroperasi. Biaya total didapatkan dari penjumlahan biaya tetap dan biaya tidak tetap. Adapun total biaya rata-rata per tahun dalam kegiatan usaha penagkapan bagan tancap sebesar Rp.54.007.289,-

Tabel 4. Rata-rata Total Biaya Investasi, Biaya Tetap dalam 1 tahun

\begin{tabular}{lcc}
\hline $\begin{array}{c}\text { Nama } \\
\text { Nelayan }\end{array}$ & $\begin{array}{c}\text { Biaya Investasi } \\
\text { (dalam rupiah) }\end{array}$ & $\begin{array}{c}\text { Biaya Tetap } \\
\text { (dalam rupiah) }\end{array}$ \\
\hline Samsudin & 54.297 .000 & 11.661 .042 \\
Lematiro & 62.570 .000 & 37.172 .857 \\
Hj. Akbar & 53.955 .000 & 17.291 .666 \\
Arsad & 28.005 .000 & 16.788 .333 \\
Riski & 36.695 .000 & 13.413 .000 \\
Alias & 36.860 .000 & 16.720 .667 \\
Mustring & 31.280 .000 & 28.776 .000 \\
Tulla & 27.200 .000 & 5.584 .762 \\
Misran & 98.340 .000 & 26.284 .286 \\
Udro & 113.030 .000 & 21.988 .571 \\
Alimudin & 33.457 .000 & 11.639 .000 \\
Rata-rata & 52.335 .364 & 18.847 .289 \\
\hline Sumber:
\end{tabular}

Tabel 5. Rata-rata Total Biaya Tidak Tetap (Biaya Variable), dan Total Biaya

\begin{tabular}{lll}
\hline Nama & Biaya Variable & Total biaya \\
\hline Samsudin & 54.297 .000 & 66.501 .042 \\
Lematiro & 28.800 .000 & 65.972 .857 \\
Hj. Akbar & 12.720 .000 & 30.011 .666 \\
Arsad & 30.600 .000 & 47.388 .333 \\
Riski & 42.840 .000 & 56.253 .000 \\
Alias & 35.640 .000 & 52.360 .667 \\
Mustring & 30.840 .000 & 59.616 .000 \\
Tulla & 47.640 .000 & 53.224 .762 \\
Misran & 34.800 .000 & 61.084 .286 \\
Udro & 30.000 .000 & 51.988 .571 \\
Alimudin & 38.040 .000 & 49.679 .000 \\
Rata-rata & 35.110 .636 & 54.007 .289 \\
\hline
\end{tabular}

\section{Hasil Tangkapan Bagan Tancap}

Penerimaan (output) dalam usaha penangkapan ikan merupakan nilai penjualan hasil tangkapan. Besarnya pendapatan dipengaruhi oleh produktivitas alat tangkap, perubahan musim yang disebabkan perubahan cuaca dan iklim dan fluktuasi harga ikan baik perubahan harga dari waktu ke waktu yang disebabkan oleh produk hasil perikanan bersifat sangat mudah rusak dan akibat perubahan sementara dalam penawaran dan permintaan serta nilai ekonomis atau nilai jualhasil tangkapan. Penerimaan rata-rata nelayan bagan tancap selama satu tahun adalah sebesar Rp.138.469.091/tahun. Dalam usaha penangkapan ikan, penerimaan sangat tidak menentu tergantung dari jumlah ikan yang didapatkan. Hal ini dipengaruhi oleh musim penangkapan ikan dan kondisi perairan daerah penangkapan.

Hasil tangkapan bagan tancap tersaji pada Tabel 6.

Tabel 6. Rata-rata Penerimaan usaha alat tangkap bagan tancap di PPI Kurau dalam 1 tahun

\begin{tabular}{lc}
\hline Nama Nelayan & $\begin{array}{c}\text { Penerimaan } \\
\text { (dalam rupiah) }\end{array}$ \\
\hline Samsudin & 132.000 .000 \\
Lematiro & 136.400 .000 \\
Hj. Akbar & 100.500 .000 \\
Arsad A.S & 154.500 .000 \\
Riski & 134.380 .000 \\
Alias & 139.780 .000 \\
Mustring & 132.100 .000 \\
Tulla & 117.000 .000 \\
Misran & 133.500 .000 \\
Udro & 185.000 .000 \\
Alimudin & 158.000 .000 \\
Rata-Rata & 138.469 .091 \\
\hline
\end{tabular}

\section{Pendapatan}

Keuntungan

merupakan total pendapatan bersih yang diperoleh dari total pendapatan dikurang dengan total biaya yang dikeluarkan (Tabel 7).

Keuntungan adalah total penerimaan setelah dikurangi biaya produksi (biaya yang dibayarkan) dan biaya yang diperhitungkan dalam hal ini biaya yang diperhitungkan pada usaha bagan tancap ini adalah biaya implicit yaitu upah tenaga kerja yang berasal dari dalam keluarga. Adapun keuntungan usaha perikanan bagan tancap di PPI Kurau ratarata sebesar Rp.52.842.892/tahun, besarnya keuntungan tersebut didapat karena dapat dilihat dari rutinnya trip/bulan yang dilakukan nelayan, serta potensi perikanan tangkap di perairan Bangka masih berlimpah. Bangka belitung memiliki sumberdaya kelautan dan perikanan yang melimpah, baik dari segi 
kuantitas maupun diversitas, terutama perikanan tangkap. Semakin besar hasil tangkapan pada setiap trip yang di dapat nelayan maka semakin besar hasil pendapatan bersih yang didapat oleh nelayan

Pendapatan adalah total penerimaan setelah dikurangi dengan biaya produksi (biaya yang dibayarkan). Adapun rata-rata pendapatan nelayan alat tangkap bagan tancap sebesar Rp. 85.521.896/tahun. Menurut Rahim dan Astuti (2007), pendapatan mempunyai hubungan yang erat dengan tingkat produksi, apabila produksi meningkat maka pendapatan cenderung meningkat dan sebaliknya.

Tabel 7. Rata-rata Keuntungan dan Pendapatan usaha alat tangkap bagan tancap di PPI Kurau dalam 1 tahun

\begin{tabular}{ccc}
\hline Nama & $\begin{array}{c}\text { Keuntungan } \\
\text { (Tahun) }\end{array}$ & $\begin{array}{c}\text { Pendapatan } \\
\text { (Tahun) }\end{array}$ \\
\hline Samsudin & 65.498 .958 & 77.160 .000 \\
Lematiro & 43.157 .143 & 70.427 .143 \\
HJ. Akbar & 46.188 .334 & 70.488 .334 \\
Arsad A.S & 79.211 .667 & 107.111 .667 \\
Riski & 46.213 .000 & 78.127 .000 \\
Mustring & 45.214 .000 & 72.484 .000 \\
Alias & 52.835 .333 & 87.419 .333 \\
Tulla & 35.875 .238 & 63.775 .238 \\
Misran & 45.145 .714 & 72.415 .714 \\
Udro & 61.011 .429 & 133.011 .429 \\
Alimudin & 60.921 .000 & 108.321 .000 \\
Rata-rata & 52.842 .892 & 85.521 .896 \\
\hline
\end{tabular}

\section{Analisis Kelayakan}

Analisis kelayakan umumnya digunakan untuk mengukur apakah kegiatan usaha yang dilakukan pada saat ini berhasil atau tidak. Analisis usaha bagan tancap di Kabupaten Bangka Tengah tersaji pada Tabel 8 dan Tabel 9.

Return On Invesment adalah salah satu bentuk dari rasio profitabilitas yang dimaksudkan untuk mengukur kemampuan perusahaan dengan keseluruhan dana yang ditanamkan dalam aktiva yang digunakan untuk operasi perusahan untuk menghasilkan keuntungan operasi tersebut (Munawir, 2007). Hasil analisi usaha kelayakan pada 11 responden nelayan berdasarkan parameter Return of Investment (ROI), bahwa nilai ROI yang diperoleh dari 11 responden layak dikembangkan karena mempunyai nilai ROI $>1$ yaitu 125,87 \% dimana nilai ROI yang tinggi ini terjadi karena 11 usaha tersebut mempunyai penerimaan yang sangat baik.
ROI di pengaruhi oleh dua faktor yaitu tingkat perputaran aktiva yang digunakan untuk operasi perusahaan dan profit /keuntungan operasi yang dinyatakan dalam persentase dan jumlah penjualan bersih.

Tabel 8. Analisis NPV, B/C, dan IRR

\begin{tabular}{llll}
\hline $\begin{array}{l}\text { Nama } \\
\text { Nelayan }\end{array}$ & NPV & B/C & IRR (\%) \\
\hline Samsudin & 188.127 .076 & 1.98 & 94,099 \\
Lematiro & 103.806 .113 & 2.06 & 60,034 \\
Hj. Akbar & 148.018 .301 & 3.34 & 150,080 \\
Arsad & 257.558 .589 & 3.26 & 165,089 \\
Riski & 124.245 .279 & 2.38 & 77,049 \\
Alias & 152.921 .324 & 2.66 & 97,051 \\
Mustring & 117.394 .778 & 2.21 & 70.059 \\
Tulla & 82.944 .505 & 2.19 & 61,021 \\
Misran & 110.272 .313 & 2.18 & 68,046 \\
Udro & 179.588 .473 & 3.55 & 101,049 \\
Alimudin & 186.050 .543 & 3.18 & 102,001 \\
Rata-rata & 150.084 .299 & 2.63 & $70,00 \%$ \\
\hline
\end{tabular}

Tabel 9. Analisis ROI dan PP

\begin{tabular}{llll}
\hline No. & Nama & ROI (\%) & PP \\
\hline 1 & Samsudin & 120,62 & 0.82 \\
2 & Lematiro & 68,97 & 1.4 \\
3 & Hj. Akbar & 85,60 & 1.1 \\
4 & Arsad & 282,84 & 0.35 \\
5 & Riski & 125,93 & 0.79 \\
6 & Mustring & 144,54 & 0.69 \\
7 & Alias & 143,34 & 0.69 \\
8 & Tulla & 131,89 & 0.75 \\
9 & Misran & 45,90 & 2.1 \\
10 & Udro & 53,97 & 1.8 \\
11 & Alimudin & 182,08 & 0.54 \\
Rata-rata & $125,87 \%$ & 1.00 \\
\hline
\end{tabular}

Payback periods adalah jangka waktu kembalinya investasi yang telah dikeluarkan melalui keuntungan dari suatu bisnis atau usaha yang diberikan investasi itu. Jika dilihat rata-rata dari 11 responden didapatkan nilai PP sebesar 1,00 atau sama dengan satu tahun. Adapun kritria nilai Payback period ini cukup singkat, sehingga usaha ini layak untuk dijalankan yaitu nilai Payback Period kurang dari 3 tahun pengembalian modal usaha dikategorikan cepat. Nilai Payback Period lebih dari 5 tahun dikategorikan pengembalian lambat. Menurut Farhaby (2019) kegiatan usaha perikanan layak untuk di operasikan apabila pengembalian modal lebih pendek waktunya dari pada maksimum waktu balik modal. 
Benefit-Cost Ratio (Net B/C) Perhitungan $b / c$ ratio sangat penting dalam perhitungan usaha untuk mengetaui keuntungan analisis imbangan biaya dan penerimaan adalah alat analisis tingkat efisiensi setiap rupiah yang dikeluarkan yang diperoleh dari penerimaan. Analisis ini akan menguji seberapa jauh setiap nilai rupiah yang akan dipakai dapat memberikan sejumlah nilai penerimaan sebagai manfaatnya. Adapun nilai B/C Ratio yang diperoleh pada penelitian ini rata-ratanya 2.63 dimana nilai ini $>1$, artinya secara keseluruhan nilai BCR nya lebih dari 1 maka investasi usaha teri krispi tersebut dianggap layak dan menguntungkan bagi usaha dimasa yang akan datang (Firdaus dan Komalasari, 2010).

Parameter Net Present Value (NPV) digunakan untuk mengetahui kelayakan usaha perikanan bangan tancap berdasarkan selisisih anatara nilai sekarang (present) dari penerimaan dengan nilai sekarang dari pengeluaran pada tingkat bunga tertentu yang berlaku. Adapun suku bunga yang berlaku 9,95\%, mengacu pada PT Bank Negara Indonesia (Persero) Tbk (BNI). Hasil analisis kelayakanusaha perikanan bagan tancap di Pangkalan Pendaratan Ikan Kurau Bangka Tengah berdasarkan tabel 8. Nilai NPV untuk perikanan bagan tancap di PPI Kurau Bangka Tengah 5 tahun kedepan adalah Rp. 150.084.299 Menurut Soeharto (2002), semakin tinggi NPV suatu usaha, maka semakin baik pula usaha tersebut dan suatu usaha dikatakan layak apabila memiliki nilai NPV yang besar. Dalam usaha ini semua nelayan memiliki nilai NPV $>0$, artinya produk tersebut layak untuk diusahakan.

Internal Rate of Return (IRR) merupakan tingkat bunga yang menggambarkan bahwa antar benefit(penerimaan) yang telah dipresent valuekan dan cost (pengeluaran) yang telah dipresent valuekansama dengan nol. Kriteria investasi IRR ini memberikan pedoman bahwa usaha akan dipilih apabila IRR > discount rate, begitu pula sebaliknya, jika diperoleh IRR < discount rate, maka usaha sebaiknya tidak dijalankan. Rata-rata nilai IRR usaha perikanan bagan tancap di Pangkalan Pendaratan Ikan Kurau Bangka Tengah $70 \%$ dalam waktu 5 tahun dimana nilai ini lebih dari discount rate pada nilai Internal Rate of Return tersebut lebih besar dari discount factor yaitu 9,95\%, jadi dapat dikatakan bahwa usaha perikanan ini layak untuk diteruskan.

\section{KESIMPULAN}

Analisis kriteria investasi dari 11 responden nelayan yang menggunakan alat tangkap bagan tancap di Pangkalan Pendaratan Ikan (PPI) Kurau Bangka Tengah, semuanya memenuhi kriteria kelayakan, didapatkan nilai $\mathrm{B} / \mathrm{C}$ ratio rata-rata 2,63 , PP (Payback Periode) 1,00 tahun, ROI (Return Of Invesment) 125,87 \%, NVP (Net Present Value) 150.001.290, dan nilai IRR rata-rata $95 \%$ dimnana lebih besar dari nilai bunga, yang berarti semua kegiatan penangkapan usaha bagan tancap dapat dikatakan layak (feasible) dilanjutkan.

\section{REFERENSI}

Dahlan, M.N. 2011. Pembangunan Perikanan tangkap di Kabupaten Belitung: Suatu Analisis Trade-off Ekonomi berbasis Lokal. (Tesis). Sekolah Pasca Sarjana Institut Pertanian Bogor.

Djamin, Z. 1984. Perencanaan Dan Analisa Proyek Pertanian. Lembaga Penerbit Fakultas Ekonomi Universitas Indonesia. Jakarta

[DKP] Dinas Kelautan dan Perikanan. 2009. Peraturan Menteri Kelautan dan Perikanan Nomor PER.03/MEN/2009 tentang Penangkapan Ikan dan/atau Pengangkutan Ikan di Laut Lepas. Jakarta: DKP.

Dinas Kelautan dan perikanan Bangka Tengah. 2018. Laporan Tahunan UPT TPI Kurau Tahun 2018. Provinsi Kepulauan Bangka Belitung

Farhaby, A.M., 2019. Analisis Usaha Perikanana Tangkap Kapal Bagan di Pulau Celagen Kecamamat Pongok Kabupaten Bangka Selatan. Jurnal Aquatic Science, 1(1):33-37

Firdaus, M., dan Komalasari, L. 2010. Feasibility Analyses of Integrated Broiler Production. Media Peternakan, Journal of Animal Science and Technology, 33(3):182-188.

https://doi.org/10.5398/medpet.2010.3 3.3.182

Munawir, S. 2007. Analisa Laporan Keuangan. Edisi Keempat. Liberty. Yogyakarta.

Pratama, F.A., Boesono, H., \& Trisnani, D.H. 2012. Analisis Kelayakan Finansial Usaha Penangkapan Ikan menggunakan Panah dan Bubu Dasar di Perairan Karimunjawa. Journal of Fisheries Resources Utilization Management and Technology, 1(10):22-31. 
Rahim, A dan Hastuti, D.R.D. 2007. Ekonomika Pertanian, Pengantar teori dan Kasus, Penebar Swadaya

Soeharto, I. 2002. Studi Kelayakan Proyek Industri. Erlangga. Jakarta.

Sugiyono. 2012.Memahami Penelitian Kuantitatif. Bandung: Alfabeta

Takril. 2005. Hasil Tangkapan Sasaran Utama dan Sampingan Bagan Perahu di Polewali Kabupaten Polewali Mandar,
Sulawesi Barat. Skripsi [tidak dipublikasikan]. Bogor: Program Studi Pemanfaatan Sumbrdaya Perairan, Fakultas Perikanan dan Ilmu Kelautan, Institut Pertanian Bogor. 61 hal.

Umar, H, 2003. Studi Kelayakan Bisnis : Teknik Menganalisis Kelayakan Rencana Bisnis secara Komprehensif. Edisi ketiga revisi. Jakarta : PT Gramedia Pustaka Utama 